\title{
A NEW TYPE OF AT-SPECIFIC LIGAND CONSTRUCTED OF TWO NETROPSIN-LIKE MOLECULES
}

\author{
A. A. KHORLIN, A. S. KRYLOV, S. L. GROKHOVSKY, A. L. ZHUZE, A. S. ZASEDATELEV, \\ G. V. GURSKY and B. P. GOTTIKH \\ Institute of Molecular Biology, USSR Academy of Sciences, Vavilov str., 32, 117984 Moscow' V-334, USSR
}

Received 15 July 1980

\section{Introduction}

Solving the problem of recognition of specific nucleotide sequences on double-stranded DNA by regulatory proteins is one of the main goals of molecular biology. In systems modelling protein-nucleic acid recognition one can make use of low molecular weight compounds possessing affinity for definite short base sequences of DNA $[1,2]$. Among these compounds, antibiotics distamycin (DM) and its analog netropsin $(\mathrm{Nt})$ are the most thoroughly studied [3-7]. Stereochemical models for DM-DNA and $\mathrm{Nt}$-DNA complexes have been suggested and corroborated [3-7]. According to these models upon binding of DM (or Nt) to DNA the oligopyrrolcarboxamide backbone of the antibiotic molecule is localized in the minor DNA groove forming a helix isogeometric to the DNA $\beta$-helix. The AT specificity of binding is a consequence of formation of hydrogen bonds which connect the antibiotic amide groups with thymine $\mathrm{O} 2$ and adenine $\mathrm{N} 3$ atoms lying in the same polynucleotide chain and exposed in the minor DNA groove. The binding is stereospecific in a sense that $\mathrm{CO} \rightarrow \mathrm{NH}$ direction in the antibiotic carboxamide groups coincides with $\mathrm{C} 5^{\prime} \rightarrow \mathrm{C} 3^{\prime}$ direction in the corresponding polynucleotide chain.

Here we describe a new approach to designing sequence specific ligands. Each ligand contains two netropsin-like molecules linked by a flexible chain in such a way that the $\mathrm{CO} \rightarrow \mathrm{NH}$ directions in the two moieties are antiparallel. This approach allows an increase in the number of AT-specific recognition centers in a ligand molecule, thereby increasing its binding specificity. We have obtained a series of ligands each capable of interacting by its two Nt-like fragments with two stretches of adenine and thymine bases lying in the opposite DNA strands. Fig.1 shows chemical formulae of the compounds synthesized which are distinguished by the number of methylene groups in a flexible chain linking the two Nt-like fragments.

\section{Materials and methods}

Compounds $1 \mathrm{a}-\mathrm{d}$ were synthesized by interaction of compound II with di-4-nitrophenylsuccinate [8], di- $N$-hydroxysuccinimide esters of adipic, suberic and decane dicarboxilic acids, respectively. The condensations were carried out in $N, N$-dimethylformamide solution, the ratio of an activated ester and compound II being $1: 2.1$. The reaction products $1 \mathrm{a}-\mathrm{d}$ were isolated by 2 -fold chromatography on a Sephadex LH-20 column $(150 \times 2.5 \mathrm{~cm})$ with $62-75 \%$ yield. Their homogeneity was proved by electrophoresis on FN-16 paper (Filtrak, GDR) in $1 \mathrm{M} \mathrm{AcOH}$ $(\mathrm{pH} 2.4)$ at $20 \mathrm{~V} / \mathrm{cm}$. Electrophoretic mobilities (against glycine) were $0.8 \pm 0.02$ for compounds $1 \mathrm{a}-\mathrm{d}$ and $1.4 \pm 0.02$ for compound II.

The UV spectra were measured with a Cary 118 spectrometer (USA) using $1 \mathrm{~cm}$ pathlength cells. The CD spectra were obtained with a Jobin-Yvon Mark III dichrograph (France) applying $0.1 \mathrm{~cm}, 1 \mathrm{~cm}$ and $2 \mathrm{~cm}$ pathlength cells. Fluorescence spectra were measured with an Aminco SPF-1000 CS instrument (USA). Poly $(\mathrm{dA}) \cdot$ poly $(\mathrm{dT})$ was from P.L. Biochemicals (USA); calf thymus DNA was from Sigma (USA). All polynucleotides were used as supplied without further purification. All polynucleotide solutions were dialysed for $6 \mathrm{~h}$ against $0.06 \mathrm{M}$ phosphate buffer 


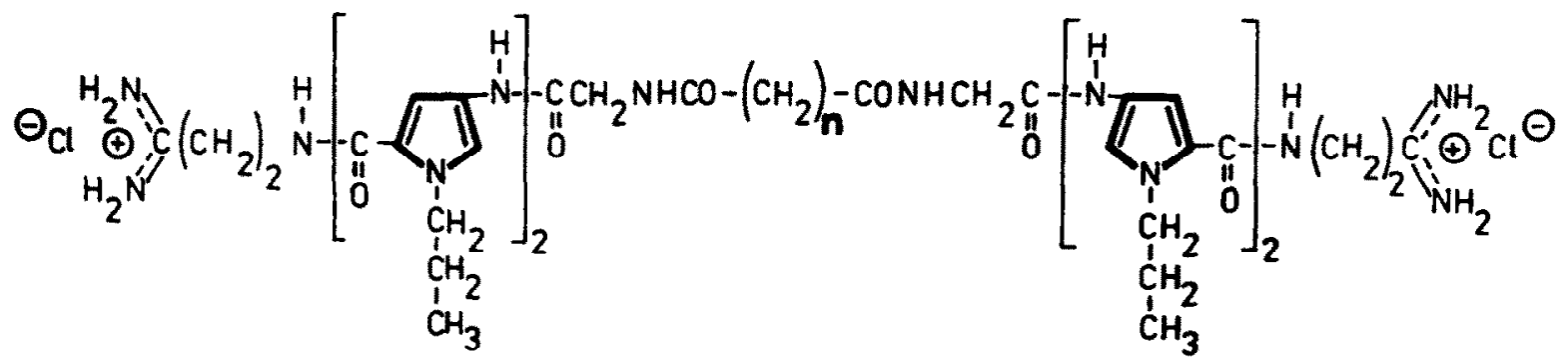

(Ia) $n=2 ;(I b)_{n=4 ;}(I c) \mid n=6 ;(I d) ~ n=10$

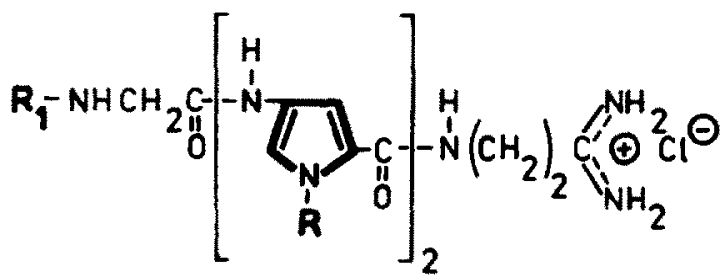

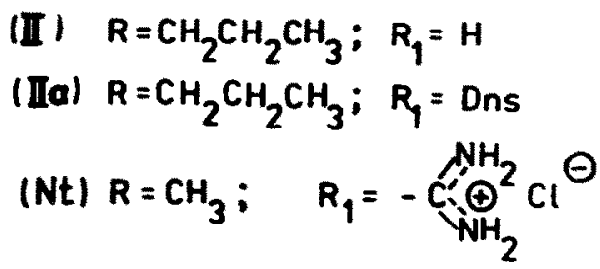

Fig.1. Chemical formulae of compounds synthesized $(1 \mathrm{a}-1 \mathrm{~d})$, netropsin (Nt) and Nt analogs (II and IIa).

( $\mathrm{pH}$ 6.0) containing $5 \times 10^{-4} \mathrm{M}$ Na EDTA and then dialysed for $24 \mathrm{~h}$ against $0.06 \mathrm{M}$ phosphate buffer ( $\mathrm{pH} 6.0$ ) in the absence of EDTA. All binding experiments were carried out in $0.06 \mathrm{M}$ phosphate buffer $(\mathrm{pH} 6.0)$ at $20^{\circ} \mathrm{C}$.

\section{Results and discussion}

The absorption spectra of compound $1 \mathrm{c}$ and the Nt-like compound II are given in fig.2. The shapes of the two absorption spectra are similar but the molar extinction of $1 \mathrm{c}$ is, however, twice as large as that of II. The additive contribution of two Nt-like fragments demonstrates that these two moieties do not interact with each other in solution. Addition of DNA markcdly affects the spectrum of 1c (fig.2). The observed spectral changes exhibit a similarity to those detected on binding compound II to DNA. Similar results were obtained from binding compounds $1 \mathrm{a}, 1 \mathrm{~b}$ and $1 \mathrm{~d}$ to DNA.

The CD spectra of compounds $1 \mathrm{c}$ and II complexed with poly $(\mathrm{dA}) \cdot \operatorname{poly}(\mathrm{dT})$ are shown in fig.3, from which it can be secn that they are similar. Ilowever, the molar ellipticity of the complex 1c-poly$(\mathrm{dA}) \cdot \operatorname{poly}(\mathrm{dT})$ is twice as large as that of the com- plex II-poly $(\mathrm{dA}) \cdot \operatorname{poly}(\mathrm{dT})$. This observation can be explained if both Nt-like fragments of $1 c$ bind to DNA independently in virtually the same manner as does II. This conclusion is also supported by our measurements of sizes of DNA sites occupied by mole. cules of $1 \mathrm{c}$ and II. Fig. 4 represents the dependences of $C D$ amplitude at $315 \mathrm{~nm}$ obtained on titration of poly $(\mathrm{dA}) \cdot \operatorname{poly}(\mathrm{dT})$ and calf thymus DNA with $1 \mathrm{c}$

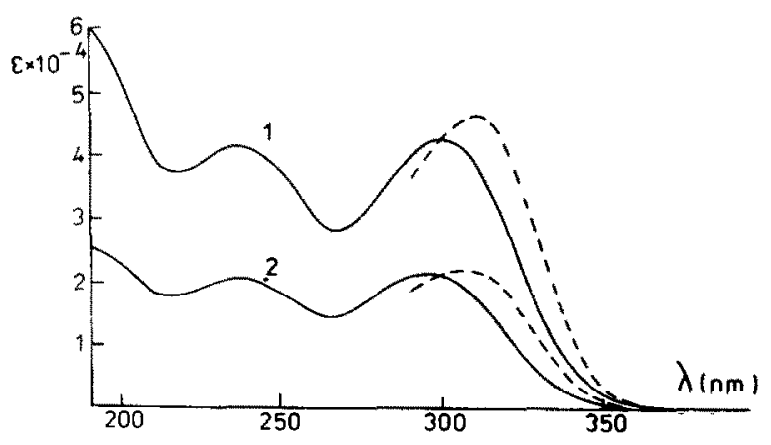

Fig.2. Absorption spectra of compounds $1 \mathrm{c}(1)$ and 11 (2): $\left(-{ }_{-}\right)$in the free state; $\left({ }_{--}\right)$in the complex with calf thymus DNA. $\epsilon=$ molar extinction coefficient. Ligands were $0.8 \times 10^{-5} \mathrm{M}$. DNA was $1.6 \times 10^{-4} \mathrm{M}$ (basepairs). The spectra were measured in $0.06 \mathrm{M}$ phosphate buffer $(\mathrm{pH} 6.0$ at $20^{\circ} \mathrm{C}$. 


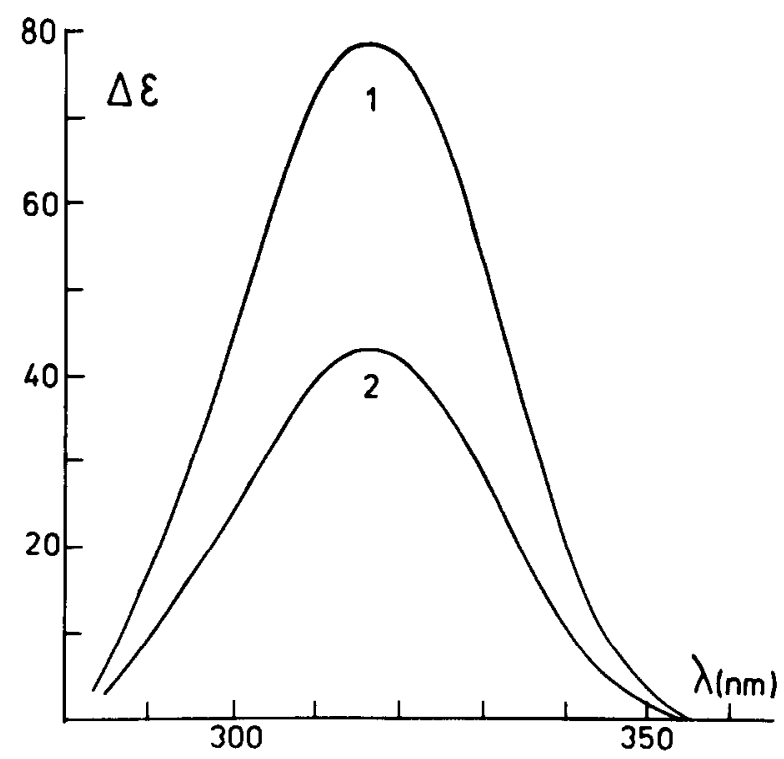

Fig. 3. CD spectra of compounds $1 \mathrm{c}(1)$ and II (2) complexed with poly $(\mathrm{dA}) \cdot \operatorname{poly}(\mathrm{dT})$. Ligands were $2.6 \times 10^{-6} \mathrm{M}$, DNA was $4.1 \times 10^{-5} \mathrm{M}$ (basepairs). The experimental conditions were identical to those in fig. 1 .

and II. From measured saturation levels of binding of these compounds we conclude that II and 1c occupy 5 and 10 basepairs, respectively, on poly $(\mathrm{dA}) \cdot$ poly(dT). Similar experiments show that compounds 1a, $1 \mathrm{~b}$ and $1 \mathrm{~d}$ occupy 7,10 and 11 basepairs, respectively. The saturation level of binding of $1 \mathrm{c}$ to calf thymus DNA (58\% AT) is lower than that of II, reflecting a higher AT-specificity of $\mathrm{Ic}$ in comparison with II.

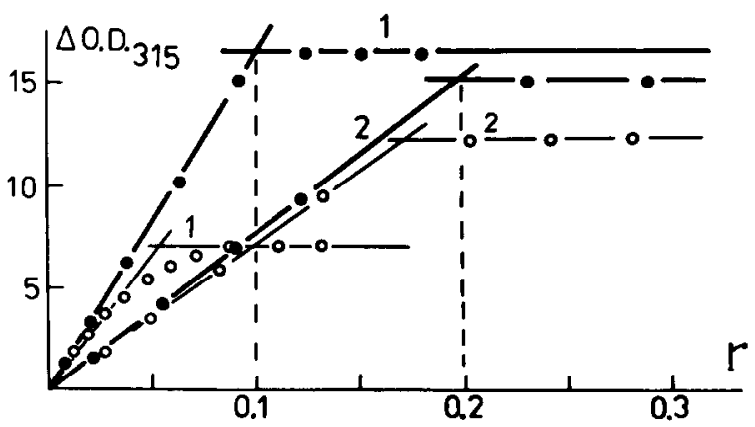

Fig.4. The CD titration of poly (d A) $\cdot$ poly $(\mathrm{dT})(\bullet)$ and calf thymus DNA (O) with compounds Ic (1) and II (2). OD $\mathrm{O}_{315}$ is the CD amplitude of the complex measured at $315 \mathrm{~nm}, r=$ $C /[P / 2]$, where $C$ is the total ligand molar concentration, $[P / 2]=3 \times 10^{-5} \mathrm{M}$ is the concentration of DNA (in basepairs).

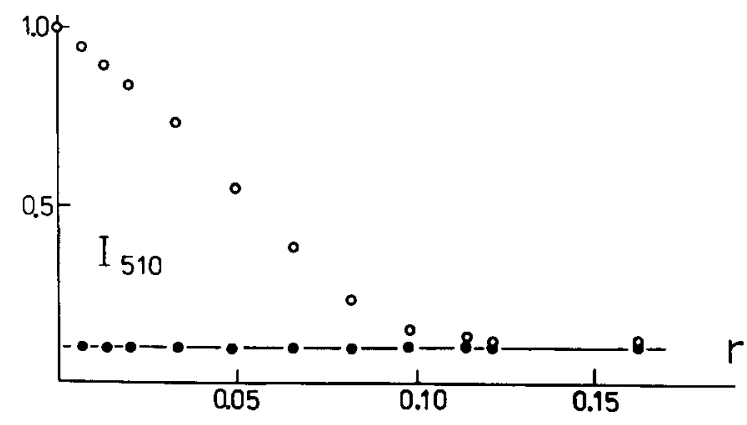

Fig.5. Displacement of fluorescent analog of Nt (IIa) from poly (dA) - poly (dT) by compound $1 \mathrm{c}, I_{510}$ is the intensity of fluorescence of IIa measured at $510 \mathrm{~nm}$ and excited at 340 $\mathrm{nm} ; r$ is as in fig.4. (o) Compound IIa complexed with poly$(\mathrm{dA}) \cdot \operatorname{poly}(\mathrm{dT}) ;(\bullet)$ compound IIa in the free state.

To estimate the binding constant of $1 \mathrm{c}$ to DNA we studied the competition for binding sites on poly. $(\mathrm{dA}) \cdot \operatorname{poly}(\mathrm{dT})$ between $1 \mathrm{c}$ and the fluorescent $\mathrm{Nt}$ analog IIa whose binding constant to poly(dA) . poly $(\mathrm{dT})$ is known to be $2 \times 10^{6}[7]$. Poly $(\mathrm{dA}) \cdot$ poly (dT) was first saturated with IIa, whose fluorescence, being low in the free state, increases dramatically upon binding to DNA. DNA saturated with IIa was then titrated with 1c. Displacement of IIa from DNA was accompanied by a decrease in the fluorescence intensity measured at $510 \mathrm{~nm}$. From the results presented in fig. 5 one can conclude that $1 \mathrm{c}$ displaces completely the fluorescent ligand IIa from DNA, when one $1 \mathrm{c}$ molecule is bound/10 basepairs $(r=0.1)$. This
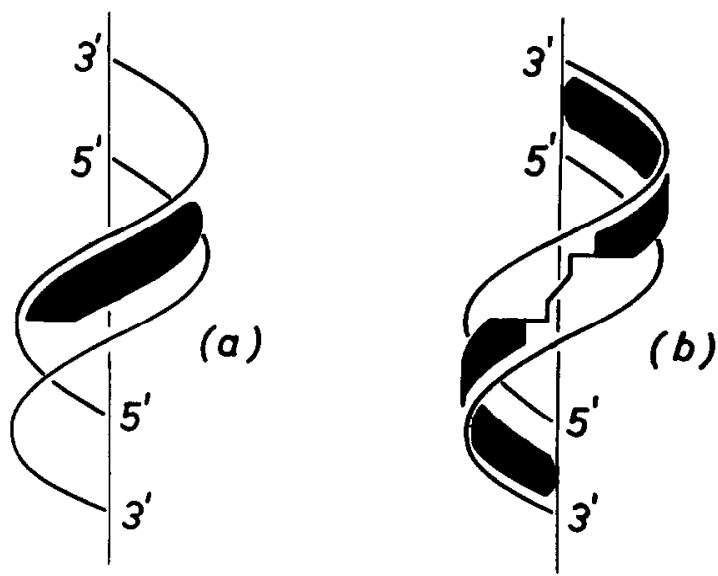

Fig.6. Schematic presentation of the geometry of complexes formed between Nt and DNS (a) as well as between compound $1 \mathrm{c}$ and DNA (b). 
demonstrates that $1 \mathrm{c}$ occupies the same binding sites on DNA as docs Nt, i.c., $1 \mathrm{c}$ molecules are attached to AT pairs in the minor groove of DNA. From these data it can also be estimated that the binding constant of $1 \mathrm{c}$ to poly $(\mathrm{dA}) \cdot \operatorname{poly}(\mathrm{dT})$ is $\geqslant 100$-times larger than that determined for binding of IIa. If two Nt-like fragments in $1 \mathrm{c}$ act independently upon binding then we can estimate the binding constant of $1 \mathrm{c}$ to be of the order of $10^{-12} \mathrm{M}^{-1}$, that is about the square of the binding constant of IIa. Experimental data on competition between the fluorescent ana$\log$ IIa and $1 \mathrm{~b}$ and $1 \mathrm{~d}$ demonstrates that the latter bind to poly $(\mathrm{d} A) \cdot \operatorname{poly}(\mathrm{dT})$ more strongly than does IIa. Evidently, each of the two Nt-like fragments in these molecules is bound to DNA. Compound 1a forms a less-stable complex with DNA, presumably because the linking chain is too short and independent binding of the two Nt-like fragments is not possible. These experiments and the data in [5-7] on binding of various analogs of DM to DNA point toward the model for the binding of compounds $1 b-d$ to DNA illustrated in fig.6. In the complex, the two Nt-like fragments of the ligand molecule are bound to the opposite DNA strands in such a way that the complex structure possesses a $\sim 2$-fold rotational symmetry. The binding involves hydrogen bond formation between amide groups of each Nt-like fragment and 3 successive adenine (or thymine) residues lying in the same polynucleotide chain. Since thymine $\mathrm{O} 2$ and adenine $\mathrm{N} 3$ atoms in AT pairs are related by 2 -fold rotational symmetry, one can conclude that upon binding of these ligands to DNA the adenine is approximately equivalent to a thymine. The proposed model agress with our experiments showing that compounds $1 \mathrm{~b}, 1 \mathrm{c}$ and $1 \mathrm{~d}$ possess an extremely high affinity for AT-rich DNA scquences and presumably utilize the symmetry of the DNA sequence. These ligands may interact strongly with AT-rich sequences included in the so-called 'Pribnow box' $[9,10]$ in procaryotic promoters and may serve as efficient inhibitors of transcription.

\section{References}

[1] Gursky, G. V., Zasedatelev, A. S., Tumanyan, V. G., Zhuze, A. L., Grokhorsky, S. L. and Gottikh, B. P. (1979) in: 12th FEBS Meet., Dresden, 1978, vol. 51. pp. 23-32, Pergamon, Oxford, New York.

[2] Gursky, G. V., Tumanyan, V. G., Zasedatelev, A. S., Zhuze, A. L., Grokhovsky, S. L. and Gottikh, B. P. (1976) in: Nucleic Acid-Protein Recognition (Vogel, H. J. ed) pp. 189-217, Academic Press, London New York.

[3] Zimmer, Ch. (1975) Prog. Nucleic Acids Res. Mol. Biol. 15, 285-318.

[4] Luck, G., Zimmer, Ch., Reinert, K. E. and Arcamone, F. (1977) Nucleic Acids Res. 4, 2655-2670.

[5] Zasedatelev, A. S., Zhuze, A. I.., Zimmer, Ch., Grokhovsky, S. L., Tumanyan, V. G., Gursky, G. V. and Gottikh, B. P. (1976) Dokl. Akad. Nauk SSSR 231, 1006-1009.

[6] Zasedatelev, A. S., Zhuze, A. L., Zimmer, Ch., Grokhovsky, S. L., Tumanyan, V. G., Gursky, G. V. and Gottikh, B. P. (1978) Studia Biophys. 67, 47-48.

[7] Krylov, A. S., Grokhovsky, S. L., Zasedatelev, A. S. Zhuze, A. L., Gursky, G. V. and Gottikh, B. P. (1979) Nucleic Acids Res. 6, 289-304.

[8] Bishoff, C. A. and Van Hedenstrom, A. (1902) Chem. Ber. 35, 4079-4084.

[9] Pribnow, D. (1975) Proc. Natl. Acad. Sci. USA 72. 784-788.

[10] Sicbenlist, U. (1979) Nucleic Acids Res. 6, 1895-1907. 